\title{
Alterations in Circulating Levels of Vitamin D Binding Protein, Total and Bioavailability of Vitamin $D$ in Diabetes Retinopathy Patients
}

Zhila Maghbooli ( $\sim$ zhilayas@gmail.com )

Tehran University of Medical Sciences

Sepideh Ebrahimi Meimand

Tehran University of Medical Sciences

Ali-asghar Malek Hosseini

Tehran University of Medical Sciences

Arash Shivani

Tehran University of Medical Sciences

\section{Research Article}

Keywords: Type 2 Diabetes mellitus, Retinopathy, Vitamin D binding protein, vitamin D, bioavailability of vitamin D

Posted Date: February 3rd, 2022

DOI: https://doi.org/10.21203/rs.3.rs-1169116/v1

License: (c) (i) This work is licensed under a Creative Commons Attribution 4.0 International License. Read Full License 


\section{Abstract}

Aims

The aims of this study were to investigate the association between circulating levels of vitamin $D$ binding protein (VDBP) and its genotypes and diabetic retinopathy risk.

\section{Methods}

In this study, 154 patients with type 2 diabetes mellitus; 62 with diabetic retinopathy (DR) and 92 without DR/and or diabetic nephropathy (DN), were recruited. Circulating levels of 25-hydroxyvitamin D3 and VDBP levels were measured in the patients. The genotype and phenotype of VDBP were evaluated based on two common VDBP variations; rs7041 and rs4588.

\section{Results}

Serum levels of VDBP were significantly lower in patients with DR than in patients without DR/and or DN $(\operatorname{Ln}-\operatorname{VDBP}(\mu \mathrm{g} / \mathrm{ml}): 6.14 \pm 0.92$ vs. $6.73 \pm 1.45, \mathrm{p}=0.001)$ even after adjustment for age, sex, body mass index, disease duration, eGFR, $\mathrm{HbA1C}$, and serum levels of 25(OH)D. The distribution of VDBP phenotypes and genotypes in the two studied groups were nearly the same, and the distribution was similar to that of the general population.

\section{Conclusions}

In this study, we found out the association between lower levels of VDBP and risk of DR. However, the precise mechanism linking these two remains unknown. Further and more in-depth research to find out the underlying causes of the relationship is needed.

\section{Introduction}

Diabetes retinopathy (DR) is one of the most common etiologies for visual loss in people between the ages of 20-64 [1]. It is the first etiology of preventable blindness in the working-age (20-45) population in developed countries, and the estimated prevalence of diabetic retinopathy is $18.45 \%$ [2-5]. Poor glycemic control and disease duration are the main important risk factors of DR. However, abnormal metabolic environmental factors like vitamin $D$ deficiency increase the risk of developing diabetic retinopathy [611]. Vitamin $D$ may have a role in the pathogenic mechanisms predisposing to diabetes complications through dysregulating in glucose homeostasis, modulating insulin resistance, and/or pancreatic $\beta$-cell function $[12,13]$.

A meta-analysis concluded that there is not enough evidence supporting the efficacy of vitamin D supplementation in complications of type 2 diabetes[14]. The study reported that vitamin D supplementation has no proved effect on fasting glucose levels, impaired glucose tolerance, improving insulin resistance and glycemic control in diabetic patients [14]. On the other hand it has been reported 
that moderate to high doses of vitamin D may reduce the risk of cardiovascular disease [15]. Indeed using vitamin $D$ supplementation may reduce the risk of progression from prediabetes to diabetes [16]. These discrepancies may be caused by vitamin D binding protein (VDBP) dysregulation in diabetes patients.

VDBP, the key determinant of vitamin D, can efficiently affect the sustainability, biocompatibility, and biological performance of vitamin D. Vitamin $\mathrm{D}$ and its metabolites should pass the cell membrane in VDBP complex form to have their function and attach to the nuclear vitamin D receptor [17]. VDBP (P02774), is a polymorphic protein from the albumin family, which is known as the main carrier of active metabolites of vitamin D (85-90\%) $[18,19]$. It is synthesized in the liver and its concentration is stable during life comparatively. However, liver failure, proteinuria, and malnutrition lead to lower circulating levels of VDBP $[20,21]$. VDBP has a high affinity to the principal vitamin D metabolites; around $85 \%$ of circulating $25(\mathrm{OH}) \mathrm{D}$ and $1,25(\mathrm{OH}) 2 \mathrm{D}$ carries via binding to VDBP with high affinity as approximately $15 \%$ are connected to albumin and less than $0.4 \%$ of them are free $[22,23]$. VDBP variations could regulate the bioavailability of $25(\mathrm{OH}) \mathrm{D}$ by presenting different phenotypes and circulating levels of total VDBP [24]. These findings provide novel insight into metabolic differences that may underlie racial variation of VDBP in the association between $25(\mathrm{OH}) \mathrm{D}$ and diabetes and microvascular complications. As a single marker, the total $25(\mathrm{OH}) \mathrm{D}$ level is not sufficient to accurately evaluate vitamin $\mathrm{D}$ status [25]. In cases where circulation of VDBP may be altered, VDBP measurements and bioavailable 25(OH)D calculations may help to determine vitamin D status accurately[25].

The purposes of our study were to explore the association of serum VDBP and bioavailable 25(OH)D with diabetic retinopathy and to determine the risk association of VDBP polymorphisms and diabetic retinopathy.

\section{Subjects, Materials And Methods Study population}

The study population, the inclusion and exclusion criteria, and retinopathy and nephropathy diagnosis criteria have been described previously[26, 27] and it was summarized as follow:

Patients with the diagnosis of T2DM from a referral diabetes clinic affiliated with Tehran University of medical sciences (Tehran, Iran) were recruited in this case-control study; 62 of them had retinopathy and 92 of them didn't have retinopathy or nephropathy (control group).

\section{Biochemical measurements}

Patients had overnight fasting for 10-14 hours before taking blood samples. The separated sera of the patients were kept at $-80^{\circ} \mathrm{C}$ before the analysis. The serum levels of fasting serum glucose, total cholesterol (TC), high-density lipoprotein (HDL) cholesterol, and low-density lipoprotein (LDL) cholesterol, triglycerides (TG), blood urea nitrogen (BUN), creatinine ( $\mathrm{Cr}$ ) uric-acid, and albumin were measured by an 
enzymatic colorimetric assay [Pars-Asmun kits, Iran] using an auto-analyzer (Hitachi 902, Japan) with intra-assay precision of $0.63-1.23 \%$ and intraassay precision of $1.09-1.8 \%$. Urine microalbumin and creatinine levels were measured by the same auto analyzer (Hitachi 902, Japan).

Estimating glomerular filtration rate (eGFR) was calculated based on CKD EPI Equation; for $\mathrm{Cr}>61.9$ $\mu \mathrm{mol} / /$ [if female]: GFR =144 $\times(\mathrm{Scr} / 61.9)-1.209 \times(0.993) \mathrm{Age}$, for $\mathrm{Cr}>79.6 \mu \mathrm{mol} / \mathrm{l}$ [if male] GFR = $141 \times$ (Scr/79.6)-1.209 $\times(0.993)$ Age. In our population study, serum $\mathrm{Cr}$ levels were over $61.9 \mu \mathrm{mol} / \mathrm{l}$ in women and over $79.6 \mu \mathrm{mol} / \mathrm{l}$ in men. [28].

lon exchange chromatography with a DS5 set (DREW, UK) was used for measuring glycated hemoglobin ( $\mathrm{HbA} 1 \mathrm{c})$ levels. To assess the glycemic control status in the patients, the mean $\mathrm{HbA} 1 \mathrm{c}>7 \%$ was considered as poorly controlled diabetes [29].

Serum 25(OH)D was measured by radioimmunoassay using a Biosource kit (Biosource Europe SA, Belgium); intra- and inter-assay coefficients of variation (CV) were $5.2 \%$ and $7.5 \%$, respectively. P1NP was measured by quantitative sandwich enzyme immunoassay technique (intra- and inter-assay CV was $<8 \%$ and $<10 \%$ ) (Cusabio). Parathyroid hormone (PTH) was measured by quantitative two-step sandwich immunoassay using Chemiluminescent Microparticle Immuno technique (Architect intact PTH, 8K25, Germany) with a sensitivity of $\leq 5 \mathrm{pg} / \mathrm{ml}$ at a total CV of $20 \%$ and cross-reactivity of $\leq 0.01$.

Polyclonal ELIZA kit (Mybiosource, MBS564062) was used to measure VDBP serum levels according to the manufacturer's instructions; inter-assay precision: $\mathrm{CV}<10 \%$ and intra-assay precision: $\mathrm{CV}<8 \%$. To estimate vitamin D bioavailability, we used the equation "[Bio D] $=[$ DFree $]+[$ DAlb] $=($ Kalb $[$ Alb $]+1)$. [DFree]". The vitamin D bioavailability was calculated based on serum levels of vitamin D, VDBP and albumin [30].

\section{Genotyping and phenotyping}

The extraction of DNA, the genotyping and phenotyping of VDBP have been described in our previous study [31].

The polymorphisms of VDBP in exon 11 were determined by polymerase chain reaction (PCR) and restriction fragment length polymorphism analysis (RFLP); rs7041 at codon 416 (Asp $\rightarrow$ Glu) and rs4588 at codon 420 ( $\mathrm{Thr} \rightarrow$ Lys). The analysis of RFLP shows that rs4588 genotype marked as CC ( $\mathrm{Thr} / \mathrm{Thr}$ ) (809 bp), AA (Lys/Lys) (584 and 225 bp), and AC (Lys/Thr) (584, 225, and 809 bp); and rs7041 genotype marked as GG (Glu/Glu) (577 and 232 bp), TT (Asp/Asp) (nondigested bond at 809), and TG (Asp/Glu) $(577,232$, and $809 \mathrm{bp})$. We sequenced $10 \%$ of the PCR samples directly to confirm the result of PCR-RFLP.

Three common variants of VDBP have been recognized regarding the VDBP genotypes, considering the fact that humans do not have the combination of rs4588 (T) and rs7041(C): Gc1F (rs7041 (A) and rs4588 $(G))$, Gc1S (GC1S = rs7041(C) and rs4588 (G)), and Gc2 (GC2 = rs7041 (A) and rs4588 (T)). Six phenotypes can be determined considering the genotypes: $1 \mathrm{~s} / 1 \mathrm{~s}, 1 \mathrm{~s} / 1 \mathrm{f}, 1 \mathrm{~s} / 2,1 \mathrm{f} / 1 \mathrm{f}, 1 \mathrm{f} / 2$, and $2 / 2$.

\section{Statistical analysis}


The data were analyzed by SPSS statistical software (version 20). Data were expressed as number (\%) for categorical values and mean \pm standard deviation for continuous variables. Data normality was analyzed by the Shapiro-Wilk test. Circulating levels of VDBP, PTH, and BUN had no normal distribution, so a natural Log transformation was applied to correct their normality distribution. Thereafter, the comparisons between the study groups were performed using the Student's t-test and Chi-square test for continuous variables and categorical variables (control as a reference group), respectively. Vitamin D bioavailability did not have a normal distribution. The data were showed median and interquartile range and Mann-Whiney $U$ test was used to analyze the differences in the vitamin $D$ bioavailability in the case and control groups.

The Hardy-Weinberg equilibrium (HWE) and linkage disequilibrium (LD) tests of SNP were also assessed. Notably, the participants' demographics and clinical measures were reported using descriptive statistics. The genotype and allele frequencies as well as phenotype analysis were performed by Chi-square and Fisher exact tests, respectively.

To examine the association between VDBP and DR risk, multivariable logistic regression models were used. Adjusting covariates were selected based on the parameters associated with DR, including age, sex, body mass index (BMI), poor control of glycemia, kidney dysfunction, and the disease duration. If P-value was less than 0.2 (P-value $<0.2)$, it was adjusted in multivariable logistic regression analyses. All tests were two-sided, and a P-value less than 0.05 was defined as statistically significant.

\section{Results}

\section{Baseline characteristics}

A total number of 154 diabetic patients participated in this case-control study; 62 patients were diagnosed with diabetic retinopathy and 92 of them had no distinguished DR and/or DN (control group). The age and sex ratio were nearly the same in the two groups, but DR group patients were older and disease duration was longer in them. More details on the characteristics of the subjects are available in Table 1. There were no significant differences in circulating levels of FBS, TG, LDL, and TC. Patients with DR had significantly lower levels of HDL even after adjusting for age, sex, and disease duration $(p=0.001)$. In the course of diabetes poor control $(\mathrm{HbA} 1 \mathrm{c}>7 \%)$, both groups were nearly the same; $\% 60.9$ in the DR group vs \%69.4 in the control group ( $p$-value=0.3). 
Table 1

Demographic characteristic and biochemical analysis in diabetic mellitus without retinopathy diabetic mellitus with retinopathy

\begin{tabular}{|c|c|c|c|}
\hline $\begin{array}{l}\text { Demographic } \\
\text { characteristic }\end{array}$ & $\begin{array}{l}\text { Diabetic mellitus with } \\
\text { retinopathy }(\mathrm{N}=62)\end{array}$ & $\begin{array}{l}\text { Diabetic mellitus without retinopathy } \\
\text { and/or nephropathy }(\mathrm{N}=92)\end{array}$ & $\begin{array}{l}\text { p- } \\
\text { value }\end{array}$ \\
\hline Age (years)† & $59.6 \pm 6.0$ & $55.0 \pm 6.0$ & 0.001 \\
\hline Sex (Women)‡ & 27 (43.5\%) & $53(57.6 \%)$ & 0.16 \\
\hline $\mathrm{BMI}\left(\mathrm{kg} / \mathrm{m}^{2}\right) \dagger$ & $28.9 \pm 4.6$ & $29.0 \pm 5.6$ & 0.86 \\
\hline $\begin{array}{l}\text { Disease duration } \\
\text { (year) }\end{array}$ & $16.5 \pm 6.7$ & $10.1 \pm 6.2$ & 0.00 \\
\hline \multicolumn{4}{|l|}{$\begin{array}{l}\text { Laboratory } \\
\text { outcomes }\end{array}$} \\
\hline $\mathrm{FBS}(\mathrm{mg} / \mathrm{dL})$ & $150.1 \pm 64.4$ & $143.6 \pm 46.2$ & 0.45 \\
\hline Ln BUN (mg/dL) & $3.1 \pm 0.4$ & $2.7 \pm 0.3$ & 0.001 \\
\hline $\begin{array}{l}\text { Uric acid } \\
(\mathrm{mg} / \mathrm{dL})\end{array}$ & $5.62 \pm 1.57$ & $5.10 \pm 1.33$ & 0.02 \\
\hline $\mathrm{TG}(\mathrm{mg} / \mathrm{dL})$ & $133.42 \pm 68.05$ & $157.82 \pm 94.17$ & 0.05 \\
\hline $\mathrm{TC}(\mathrm{mg} / \mathrm{dL})$ & $155.67 \pm 40.71$ & $152.82 \pm 36.76$ & 0.64 \\
\hline $\mathrm{HDL}(\mathrm{mg} / \mathrm{dL})$ & $42.19 \pm 10.13$ & $49.00 \pm 10.33$ & 0.001 \\
\hline $\mathrm{LDL}(\mathrm{mg} / \mathrm{dL})$ & $86.25 \pm 25.91$ & $81.56 \pm 23.82$ & 0.23 \\
\hline eGFR (mL/min) & $69.80 \pm 30.10$ & $92.69 \pm 27.11$ & 0.001 \\
\hline $\mathrm{Cr}(\mathrm{mg} / \mathrm{dL})$ & $1.5 \pm 0.9$ & $1.1 \pm 0.5$ & 0.001 \\
\hline $\begin{array}{l}\text { Serum albumin } \\
(\mathrm{g} / \mathrm{dL})\end{array}$ & $5.07 \pm 0.55$ & $5.26 \pm 0.96$ & 0.12 \\
\hline $\begin{array}{l}\text { Urine micro } \\
\text { albumin (mg/L) }\end{array}$ & $184.11 \pm 45.87^{*}$ & $8.36 \pm 0.97 *$ & 0.001 \\
\hline $\begin{array}{l}\text { 25(OH)D } \\
\text { (ng/mL) }\end{array}$ & $18.5 \pm 11.6$ & $21.4 \pm 10.2$ & 0.08 \\
\hline Ln PTH (pg/mL) & $3.8 \pm 0.6$ & $3.5 \pm 0.4$ & 0.01 \\
\hline \multicolumn{4}{|c|}{$\begin{array}{l}\text { Abbreviations: BMl; body mass index, BUN; blood urea nitrogen, Cr; creatinine, eGFR; Estimating } \\
\text { glomerular filtration rate, FBS; fasting blood serum, HDL; high-density lipoprotein, LDL; low-density } \\
\text { lipoprotein, Ln; natural logarithm, PTH; parathyroid hormone }\end{array}$} \\
\hline \multicolumn{4}{|l|}{ tmean $\pm S D$} \\
\hline
\end{tabular}


Regarding kidney function, circulating levels of BUN, uric acid, and $\mathrm{Cr}$ and urine microalbumin levels were significantly higher in the DR patients. Consequently, the eGFR levels were significantly lower in DR patients compared to diabetic patients without microvascular complications.

\section{Serum levels of vitamin D, vitamin D binding protein, and bioavailability of vitamin D}

In the total study population, the mean serum levels of vitamin D were $20.9 \pm 9.6 \mathrm{ng} / \mathrm{ml}$ and only $19 \%$ of patients were vitamin D sufficiency $(>30 \mathrm{ng} / \mathrm{ml})$.

In the course of DR, the prevalence of vitamin D deficiency was as similar as in the control group; $82.9 \%$ vs. $77.8 \%$, respectively, while PTH was significantly higher in the DR group.

The serum levels of VDBP were significantly lower in the DR group ( $\mathrm{Ln}-\mathrm{VDBP}(\mu \mathrm{g} / \mathrm{ml}): 6.14 \pm 0.92$ in DR group vs $6.76 \pm 1.51$ in the control group, $p=0.002$ ). As $D R$ patients were older and had longer duration of diabetes, and lower eGFR and serum levels of vitamin $D$, the logistic regression model was used to minimize their effects. After adjusting age, sex, eFGR, vitamin D levels, and disease duration, there was an independent association between lower levels of VDBP and DR risk (Beta $=0.7,95 \% \mathrm{Cl}$ lower-upper: 0.2$0.9, p=0.03)$.

In the subgroup analysis of the DR group, the VDBP levels were similar in patients with proliferative and non-proliferative diabetic retinopathy $(p=0.9)$ (Fig. 1).

There was a decreasing trend in circulating levels of VDBP in relation to retinopathy progression; (LnVDBP (ug/ml): with PDR, 6.1 \pm 0.8 ; NPDR, $6.2 \pm 0.8$; and without PDR or NPDR, $6.7 \pm 1.5(p=0.01)$ ). In the post hoc test, there was no significant difference in the circulating levels of VDBP between the PDR and NPDR subgroups ( $p=0.7$ ) (Fig. 1).

The estimation of vitamin $D$ bioavailability showed higher rates in the DR group than in the control group (median (IQR): $1.02(1.75) \mathrm{ng} / \mathrm{ml}$ vs. 0.44 (1.29), $\mathrm{p}=0.03$ ). There was no significant constant association between vitamin D bioavailability and DR after adjusting for confounder factors including, age, sex, eGFR, and disease duration $(p=0.11)$.

\section{Polymorphisms in the vitamin D-binding protein gene}

Genotyping was performed in 81 diabetic patients without retinopathy and 59 diabetic patients with retinopathy for rs 4588 and rs7041 of the VDBP gene. Table 2 presents the distribution of genotype, allele, and phenotype frequency in the DR and control groups. The genotypes based on both SNPs were consistent with Hardy-Weinberg equilibrium in the DR group ( $p=0.96$ for rs $4588, p=0.16$ for rs7041) and control ( $p=0.33$ for rs $4588, p=0.14$ for rs7041) group. 
Table 2

Genotype, allele frequency and phenotype of Vitamin D-Binding Protein Gene in diabetes retinopathy patients and control groups

\begin{tabular}{|c|c|c|c|}
\hline & $\begin{array}{l}\text { Diabetic mellitus with } \\
\text { retinopathy }(\mathrm{N}=59)\end{array}$ & $\begin{array}{l}\text { Diabetic mellitus without retinopathy and/or } \\
\text { nephropathy }(\mathrm{N}=81)\end{array}$ & $\begin{array}{l}\text { P- } \\
\text { value }\end{array}$ \\
\hline \multicolumn{4}{|l|}{$\begin{array}{l}\text { Genotype- } \\
\text { rs } 4588\end{array}$} \\
\hline $\begin{array}{l}\text { CC } \\
\text { (Thr/Thr) }\end{array}$ & $54.2 \%(32)$ & $64.2 \%(52)$ & 0.48 \\
\hline $\begin{array}{l}\text { AA } \\
\text { (Lys/Lys) }\end{array}$ & $6.8 \%(4)$ & $6.2 \%(5)$ & \\
\hline $\begin{array}{l}\text { AC } \\
\text { (Lys/Thr) }\end{array}$ & $39.0 \%(23)$ & $29.6 \%(24)$ & \\
\hline \multicolumn{4}{|l|}{$\begin{array}{l}\text { Genotype- } \\
\text { rs7041 }\end{array}$} \\
\hline $\begin{array}{l}\text { TT } \\
\text { (Asp/Asp) }\end{array}$ & $8.5 \%(5)$ & $8.6 \%(7)$ & 0.99 \\
\hline $\begin{array}{l}\text { GG } \\
\text { (Glu/Glu) }\end{array}$ & $37.3 \%(22)$ & $38.3 \%(31)$ & \\
\hline $\begin{array}{l}\text { TG } \\
\text { (Asp/Glu) }\end{array}$ & $54.2 \%(32)$ & $53.1 \%(43)$ & \\
\hline \multicolumn{4}{|l|}{$\begin{array}{l}\text { allele Freq. } \\
\text { rs } 4588\end{array}$} \\
\hline C & 0.74 & 0.75 & 0.3 \\
\hline$A$ & 0.26 & 0.25 & \\
\hline \multicolumn{4}{|l|}{$\begin{array}{l}\text { allele } \\
\text { Freq.rs7041 }\end{array}$} \\
\hline $\mathrm{T}$ & 0.29 & 0.29 & 0.3 \\
\hline G & 0.71 & 0.71 & \\
\hline \multicolumn{4}{|l|}{$\begin{array}{l}\text { GC } \\
\text { phenotype }\end{array}$} \\
\hline Gc1f, Gc1f & $1.2 \%(1)$ & $1.7 \%(1)$ & $0.7 *$ \\
\hline Gc1s, Gc1s & $38.3 \%(31)$ & $37.3 \%(22)$ & \\
\hline $\mathrm{Gc2}, \mathrm{Gc2}$ & $6.2 \%(5)$ & $6.8 \%(4)$ & \\
\hline GC1f,GC1s & $24.7 \%(20)$ & $15.3 \%(9)$ & \\
\hline
\end{tabular}




\begin{tabular}{|llll|}
\hline & $\begin{array}{l}\text { Diabetic mellitus with } \\
\text { retinopathy }(\mathrm{N}=59)\end{array}$ & $\begin{array}{l}\text { Diabetic mellitus without retinopathy and/or } \\
\text { nephropathy }(\mathrm{N}=\mathbf{8 1})\end{array}$ & $\begin{array}{l}\text { P- } \\
\text { value }\end{array}$ \\
\hline $\mathrm{GC1f}, \mathrm{GC} 2$ & $2.5 \%(2)$ & $1.7(1)$ \\
\hline $\mathrm{GC} 1 \mathrm{~s}, \mathrm{GC} 2$ & $27.2 \%(22)$ & $37.3 \%(22)$ \\
\hline$* \mathrm{fisher}$ 's exact test & \\
\hline
\end{tabular}

In both groups, the minor-allele frequency for SNP rs4588 was "A" and the dominant genotype was recognized "CC". In both groups, the minor-allele frequency for SNP rs7041 was T and the dominant genotype was recognized as the heterozygous TG. The frequencies of the genotypes according to both SNPs rs 4588 and rs7041 were no different significantly between the two groups; DR and control $(P>$ 0.05). There was no significant difference in the frequency of minor-alleles of both SNPs rs 4588 and rs7041 between the two studied groups $(P>0.05)$. Table 2 shows the distribution of the 6 possible haplotypes according to the 2 variants in both groups. The phenotype GC2-GC2 frequency was not significantly different between the DR and control groups (6.8\% in the DR group and $6.2 \%$ in the control group).

\section{Discussion}

In this study, we considered serum levels of vitamin D, VDBP and vitamin D bioavailability in patients with DR. Our data showed that serum VDBP levels were lower in DR patients than those without DR and/or DN.

There are a few studies that considered circulating levels of VDBP in diabetes and its complications. In this line of research, Fawzy and Alsel assessed the serum and urine levels of VDBP in diabetes patients. They reported a significantly increased level of urine VDBP with the degree of albuminuria. Also, the authors showed that serum VDBP was also higher in patients with microalbuminuria or macroalbuminuria compared to patients with normal levels of urine albumin [32]. Another study conducted by Tian and et al. presented elevated urine VDBP levels as a biomarker for DN [33]. Elevated levels of urine VDBP are identified in diabetes patients and are likely associated with tubule-interstitial dysfunction in patients with nephropathy [34-36]. In the normal kidney, to prevent loss of vitamin $D$ in the urine, VDBP bounds to $250 \mathrm{HD}$ and other vitamin D metabolites to reabsorb them.

In the current study, we measured serum levels of VDBP that showed a negative correlation with microalbuminuria in both groups. In our study population, DR patients were older and had longer duration of diabetes and lower eGFR compared with diabetes patients without DR. Consequently, DR patients with tubular dysfunction lose more VDBP through urine and have lower circulating levels of VDBP. Grymonprez et al. showed that there is a negative correlation between serum VDBP levels and urine VDBP levels [37]. Obviously, tubular dysfunction should be the main reason for lower serum VDBP levels in diabetes patients. 
One of the molecular mechanisms that explain the lower serum VDBP levels in DR patients with tubular dysfunction is megalin/Cubilin receptors. Megalin is a big protein receptor in the membrane that belongs to low-density lipoprotein receptors [38] and is expressed in the epithelial cells of the proximal tubule in the kidney [39]. Cubilin is known as a co-receptor of megalin [40] and it binds and internalizes many small proteins, including VDBP, retinol-binding protein, and transcobalamin [38]. The VDBP bounded to 25-OH vitamin $D$ transports freely through the glomerulus to the proximal tubules and then the complex is reabsorbed by megalin and its co-receptor [41]. The reabsorption by megalin facilitates 1a-hydroxylase activity in the epithelial cells of the proximal tubule to produce 1,25-dihydroxyvitamin D [42, 43]. A previous study by Thrailkill et al. showed that urinary excretion of megalin is enhanced in patients with microalbuminuria due to diabetes type 1 [44]. In vivo studies reported vitamin D deficiency, enhanced urinary excretion of VDBP in mouse models $[43,45]$. Enhanced urinary excretion of VDBP and 25(OH)D, and also decreased expression of megalin in the kidneys have been reported in animal models with diabetes $[46,47]$. There is a hypothesis suggesting that lower levels of serum VDBP can be secondary to megalin deficiency in diabetic patients with tubular dysfunction [48].

Megalin is also expressed in other tissues including the lung, uterus, and eye [49]. It is detected in the outermost layer of the retina and ciliary body of the eye [50]. The role of megalin in the development of the normal eye seems to be essential, but the details of the process have remained unknown to date. Our data also showed that the association between serum VDBP and DR was independent of vitamin D levels and eGFR. It is likely; the lower levels of serum VDBP in DR patients may have a pathological role in developing $\mathrm{DR}$ by megalin function in retinal cells.

Another mechanism that could explain the possible role of serum VDBP in developing DR is PTH imbalance due to vitamin $D$ deficiency. Growing evidence shows that low concentrations of 1,25dihydroxyvitamin $D$ are correlated with the risk of DR and other diabetes complications [51, 52]. However, the marked deficiency in our population may have confounded the study. In our study, the prevalence of vitamin deficiency in DR patients was as similar as in diabetic patients without DR and/or DN and in both groups over $70 \%$ patients were deficient/insufficient $(25(\mathrm{OH}) \mathrm{D}<30 \mathrm{ng} / \mathrm{mL})$. Although the serum levels of vitamin D were similar in the two groups, serum PTH levels were higher in patients with DR than those without retinopathy, which is in agreement with the results of other studies [53,54]. The higher levels of PTH as a compensatory mechanism of vitamin D deficiency in diabetes patients can stimulate inflammatory cytokines that have a role in the pathogenesis of DR $[53,55]$.

Regarding vitamin D bioavailability, our data showed higher rates in the DR group than in the control group, but the association disappeared after adjusting for confounder factors including, age, sex, eGFR, and disease duration. As expected, lower VDBP concentrations led to lower VDBP-bound 25(OH) D levels and higher vitamin D bioavailability among the DR patients. The longer disease duration and tubular dysfunction in DR patients are likely to impair 1,25-dihydroxyvitamin D reabsorption in the kidney.

Although VDBP is known as a vitamin D carrier, only $5 \%$ of its function is allocated to transporting vitamin D metabolites to its target cells [56]. VDBP binds to actin and it can depolymerize polymeric actin 
[57]. Monomeric actin easily turns into polymeric form in the plasma and results in clogging of the microvascular system, such as retinal microvessels. VDBP prevents polymerization and the subsequent clogging [58]. It is worth mentioning that in our data, the DR patients were older and had higher disease duration. By modeling, we tried to minimize the effect of the main confounding factors. However, after adjusting for eGFR, age, sex, and the disease duration, there was an independent association between lower circulating VDBP levels and DR. Indeed, there was a decreasing trend in circulating levels of VDBP in terms of progressing retinopathy; PDR and NPDR, but not statistically significant.

It points out a new concern that circulating levels of VDBP have a causality role in the development of retinopathy. One of the important functional roles of VDBP is activating macrophages [59]. Macrophage activation may be associated with DR by several mechanisms. Macrophage adhesion to the capillary endothelium can result in capillary occlusion and finally retinal ischemia $[60,61]$ by stimulation of cytokines [62-67]. TNF- $a$ is a cytokine produced by macrophages; it has an important role in DR pathogenesis [62]. It increases the permeability of retinal endothelium through downregulation of tight junction proteins' expression. Increased endothelial permeability may result in rupture of the blood-retinal barrier [63]. TNF-a is also a chemoattractant of leukocytes, which can also stimulate leukocyte adhesion and cause oxidation and produce reactive oxygen species as a result of optic nerve degeneration and retinal ganglion cells death $[64,65]$. TNF-a levels have been increased in animal models of proliferative retinopathy due to retinal neovascularization [65]. IL-1 $\beta$ is another cytokine mainly synthesized by macrophages. It can induce angiogenesis and ocular neovascularization [66]. The role of IL-1 $\beta$ in DR has been demonstrated in diabetic mouse models [67]. Taken together, macrophage activation may mediate the association of VDBP with DR.

VDBP genetic variations were also considered in metabolic disorders like diabetes [68-71]. The VDBP gene is located on chromosome $4 q 12$; which is a region that seems to be associated with plasma glucose and insulin concentrations in Pima Indians [12]. In this study, we have also investigated the two common missense VDBP polymorphisms, named rs7041 and rs8455, Based on the two SNPs, three major alleles have been recognized for the VDBP gene (GC1F, GC1S, GC2) [72]. The difference between GC1 and GC2 is due to alterations of four amino acids; 152 Gly / Glu, 311 Glu / Arg, 416 Asp / Glu, and $420 \mathrm{Arg} / \mathrm{Thr}$ [73]. The difference between GC1S and GC1F is for the substitution of aspartic acid by glutamic acid at position 416 [74]. There is controversy about the correlation between VDBP genotype polymorphisms and susceptibility to type 2 diabetes mellitus. Some studies have suggested a moderate correlation in Asians but no correlation in Caucasians $[68,69]$. Szathmary et al. reported that homozygotes for Gc 1F-1F had lower fasting insulin among other phenotypes [70]. However, Wei-Zhen et al. have reported that the distribution of genotypes according to both codons and phenotypes was approximately similar in healthy controls and diabetic patients [71]. The results of genotyping and phenotyping of VDBP showed no difference between the two studied groups. The distribution of phenotypes and genotypes according to the variants of the two determined SNPs (rs4588, rs7041) in both groups was the same with the general population. Our findings are in line with the results of previous studies that have shown no correlation between the variants of these two codons with the risk of DR. 
However, our study had some limitations. A case-control study could not show that variation in the circulating levels of VDBP is a consequence or its underlying cause of retinal or kidney damage in those patients. Therefore, further longitudinal studies will be conducted to investigate the VDBP roles in diabetic patients during the progression of DR.

Also, we did not measure urine VDBP levels and we could not conclude the exact association between microalbuminuria and urine VDBP concentration. It can be very useful for determining the role of VDBP and the more definite reason behind these findings.

Taken together, the results of this study could be beneficial in further identifying the role of VDBP in diabetic retinopathy. VDBP is a small protein from the albuminoid gene family, and its size is smaller than albumin and lost more by urinary excretion due to tubular dysfunction. Consequently, in future studies, it is possible to consider VDBP as a bio-marker for progressing microvascular complications.

\section{Conclusion}

We can conclude from the findings of this study that VDBP phenotypes and genotypes based on the rs4588 and rs7041 codons are not correlated with diabetic retinopathy. VDBP levels are lower in diabetic patients with retinopathy, which may be a result of urinary excretion of VDBP due to tubular dysfunction in diabetic patients. There is another possibility that lower levels of VDBP result in the progression of diabetic retinopathy by clogging retinal microvessels. Further investigations are needed to understand the mechanism relating VDBP to diabetic retinopathy.

\section{Declarations}

\section{Ethics approval and consent to participate}

The study was conducted in accordance with the Declaration of Helsinki. The experimental protocol was approved by Ethical Committee of the National Institute for Medical Research Development of Iran. The informed consent to participate in the study was obtained from all the study participants.

\section{Consent for publication}

Written informed consent for publication was obtained from all participants.

\section{Availability of data and materials}

The datasets generated and/or analyzed during the current study are available in the European Variation Archive (https://www.ebi.ac.uk/eva/?Submit-Data) repository, with accession number \# 10743821.

\section{Competing interests}


All authors declare that they have no known competing financial interests or personal relationships that could have appeared to influence the work reported in this paper.

\section{Contributions}

ZM was responsible for designing the review protocol and screening potentially eligible studies. She contributed to extracting and analyzing data, interpreting results and creating 'Summary of findings' tables.

SE conducted the writing the report, arbitrating potentially eligible studies, extracting and analyzing data and interpreting results.

AAM contributed to data extraction and provided feedback on the report.

AS was responsible for designing the review protocol, writing the protocol and report, conducting the search.

\section{Funding}

The project was supposed by National Institute Elite Researcher Grant Committee under award number [958271] from the National Institute for Medical Research Development (NIMAD), Tehran, Iran.

\section{Acknowledgments}

We thank S. Safari and S. Zorpaykar for their help on subject recruitment.

\section{References}

1. Chatziralli IP, Sergentanis TN, Keryttopoulos P, Vatkalis N, Agorastos A, Papazisis L: Risk factors associated with diabetic retinopathy in patients with diabetes mellitus type 2. BMC research notes 2010, 3:153.

2. Song P, Yu J, Chan KY, Theodoratou E, Rudan I: Prevalence, risk factors and burden of diabetic retinopathy in China: a systematic review and meta-analysis. Journal of global health 2018 , 8(1):010803.

3. Antonetti DA, Klein R, Gardner TW: Diabetic retinopathy. The New England journal of medicine 2012, 366(13):1227-1239.

4. Yau JW, Rogers SL, Kawasaki R, Lamoureux EL, Kowalski JW, Bek T, Chen SJ, Dekker JM, Fletcher A, Grauslund $\mathrm{J}$ et al: Global prevalence and major risk factors of diabetic retinopathy. Diabetes care 2012, 35(3):556-564.

5. Wong TY, Cheung CM, Larsen M, Sharma S, Simo R: Diabetic retinopathy. Nature reviews Disease primers 2016, 2:16012. 
6. Lu L, Lu Q, Chen W, Li J, Li C, Zheng Z: Vitamin D(3) Protects against Diabetic Retinopathy by Inhibiting High-Glucose-Induced Activation of the ROS/TXNIP/NLRP3 Inflammasome Pathway. $J$ Diabetes Res 2018, 2018:8193523.

7. Luo BA, Gao F, Qin LL: The Association between Vitamin D Deficiency and Diabetic Retinopathy in Type 2 Diabetes: A Meta-Analysis of Observational Studies. Nutrients 2017, 9(3).

8. Nadri G, Saxena S, Mahdi AA, Kaur A, Ahmad MK, Garg P, Meyer CH: Serum vitamin D is a biomolecular biomarker for proliferative diabetic retinopathy. Int J Retina Vitreous 2019, 5:31.

9. Patrick PA, Visintainer PF, Shi Q, Weiss IA, Brand DA: Vitamin D and retinopathy in adults with diabetes mellitus. Arch Ophthalmo/2012, 130(6):756-760.

10. Payne JF, Ray R, Watson DG, Delille C, Rimler E, Cleveland J, Lynn MJ, Tangpricha V, Srivastava SK: Vitamin D insufficiency in diabetic retinopathy. Endocrine practice : official journal of the American College of Endocrinology and the American Association of Clinical Endocrinologists 2012, 18(2):185193.

11. Yuan J, Zhou JB, Zhao W, Zhang RH, Cai YH, Shu LP, Qi L, Yang JK: Could Vitamin D be Associated with Proliferative Diabetic Retinopathy? Evidence from Pooling Studies. Horm Metab Res 2019, 51(11):729-734.

12. Baier LJ, Dobberfuhl AM, Pratley RE, Hanson RL, Bogardus C: Variations in the vitamin D-binding protein (Gc locus) are associated with oral glucose tolerance in nondiabetic Pima Indians. The Journal of clinical endocrinology and metabolism 1998, 83(8):2993-2996.

13. Parveen R, Kapur P, Venkatesh S, Agarwal NB: Attenuated serum 25-hydroxyvitamin D and vitamin D binding protein associated with cognitive impairment in patients with type 2 diabetes. Diabetes, metabolic syndrome and obesity : targets and therapy 2019, 12:1763-1772.

14. George PS, Pearson ER, Witham MD: Effect of vitamin D supplementation on glycaemic control and insulin resistance: a systematic review and meta-analysis. Diabetic medicine : a journal of the British Diabetic Association 2012, 29(8):e142-150.

15. Wang L, Manson JE, Song Y, Sesso HD: Systematic review: Vitamin D and calcium supplementation in prevention of cardiovascular events. Annals of internal medicine 2010, 152(5):315-323.

16. Pittas AG, Jorde R, Kawahara T, Dawson-Hughes B: Vitamin D Supplementation for Prevention of Type 2 Diabetes Mellitus: To D or Not to D? The Journal of Clinical Endocrinology \& Metabolism 2020, 105(12):3721-3733.

17. Jorde R: The Role of Vitamin D Binding Protein, Total and Free 25-Hydroxyvitamin D in Diabetes. Front Endocrinol (Lausanne) 2019, 10:79-79.

18. Blanton D, Han Z, Bierschenk L, Linga-Reddy MV, Wang H, Clare-Salzler M, Haller M, Schatz D, Myhr C, She JX et al: Reduced serum vitamin D-binding protein levels are associated with type 1 diabetes. Diabetes 2011, 60(10):2566-2570.

19. Moon M, Song H, Hong HJ, Nam DW, Cha MY, Oh MS, Yu J, Ryu H, Mook-Jung I: Vitamin D-binding protein interacts with Abeta and suppresses Abeta-mediated pathology. Cell death and differentiation 2013, 20(4):630-638. 
20. Bikle DD, Gee E, Halloran B, Haddad JG: Free 1,25-dihydroxyvitamin D levels in serum from normal subjects, pregnant subjects, and subjects with liver disease. J Clin Invest 1984, 74(6):1966-1971.

21. Schwartz JB, Lai J, Lizaola B, Kane L, Weyland P, Terrault NA, Stotland N, Bikle D: Variability in free 25(OH) vitamin D levels in clinical populations. J Steroid Biochem Mol Bio/2014, 144 Pt A:156-158.

22. Bouillon R, Van Baelen H, De Moor P: 25-Hydroxyvitamin D and its Binding Protein in Maternal and Cord Serum. The Journal of Clinical Endocrinology \& Metabolism 1977, 45(4):679-684.

23. Bouillon R, Van Assche FA, Van Baelen H, Heyns W, De Moor P: Influence of the Vitamin D-binding Protein on the Serum Concentration of 1,25-Dihydroxyvitamin D3: SIGNIFICANCE OF THE FREE 1,25DIHYDROXYVITAMIN D3 CONCENTRATION. The Journal of Clinical Investigation 1981, 67(3):589596.

24. Brink M, Johansson L, Nygren E, Ärlestig L, Hultdin J, Rantapää-Dahlqvist S: Vitamin D in individuals before onset of rheumatoid arthritis-relation to vitamin $\mathrm{D}$ binding protein and its associated genetic variants. BMC rheumatology 2018, 2(1):1-8.

25. Kim HJ, Ji M, Song J, Moon HW, Hur M, Yun YM: Clinical Utility of Measurement of Vitamin DBinding Protein and Calculation of Bioavailable Vitamin D in Assessment of Vitamin D Status. Ann Lab Med 2017, 37(1):34-38.

26. Maghbooli Z, Hossein-nezhad A, Larijani B, Amini M, Keshtkar A: Global DNA methylation as a possible biomarker for diabetic retinopathy. Diabetes Metab Res Rev 2015, 31(2):183-189.

27. Maghbooli Z, Larijani B, Emamgholipour S, Amini M, Keshtkar A, Pasalar P: Aberrant DNA methylation patterns in diabetic nephropathy. J Diabetes Metab Disord 2014, 13:69.

28. Inker LA, Astor BC, Fox CH, Isakova T, Lash JP, Peralta CA, Kurella Tamura M, Feldman HI: KDOQI US commentary on the $\mathbf{2 0 1 2} \mathrm{KDIGO}$ clinical practice guideline for the evaluation and management of CKD. American journal of kidney diseases : the official journal of the National Kidney Foundation 2014, 63(5):713-735.

29. Low HbA1c levels in a poorly controlled diabetic. Postgraduate Medical Journal 2003, 79(933):421.

30. Powe CE, Evans MK, Wenger J, Zonderman AB, Berg AH, Nalls M, Tamez H, Zhang D, Bhan I, Karumanchi SA et al: Vitamin D-Binding Protein and Vitamin D Status of Black Americans and White Americans. New England Journal of Medicine 2013, 369(21):1991-2000.

31. Maghbooli Z, Omidifar A, Varzandi T, Salehnezhad T, Sahraian MA: Reduction in circulating vitamin D binding protein in patients with multiple sclerosis. BMC Neurol 2021, 21(1):168.

32. Fawzy MS, Abu AISel BT: Assessment of Vitamin D-Binding Protein and Early Prediction of Nephropathy in Type 2 Saudi Diabetic Patients. J Diabetes Res 2018, 2018:8517929-8517929.

33. Tian X-Q, Zhao L-M, Ge J-P, Zhang Y, Xu Y-C: Elevated urinary level of vitamin D-binding protein as a novel biomarker for diabetic nephropathy. Experimental and therapeutic medicine 2014, 7:411-416.

34. Rao PV, Lu X, Standley M, Pattee P, Neelima G, Girisesh G, Dakshinamurthy K, Roberts CT, Nagalla SR: Proteomic identification of urinary biomarkers of diabetic nephropathy. Diabetes care 2007, 30(3):629-637. 
35. Bennett MR, Pordal A, Haffner C, Pleasant L, Ma Q, Devarajan P: Urinary Vitamin D-Binding Protein as a Biomarker of Steroid-Resistant Nephrotic Syndrome. Biomarker Insights 2016, 11:BMI.S31633.

36. Sato KA, Gray RW, Lemann J, Jr.: Urinary excretion of 25-hydroxyvitamin D in health and the nephrotic syndrome. The Journal of laboratory and clinical medicine 1982, 99(3):325-330.

37. Grymonprez A, Proesmans W, Van Dyck M, Jans I, Goos G, Bouillon R: Vitamin D metabolites in childhood nephrotic syndrome. Pediatric nephrology (Berlin, Germany) 1995, 9(3):278-281.

38. Bouillon R, Schuit F, Antonio L, Rastinejad F: Vitamin D Binding Protein: A Historic Overview. Front Endocrinol (Lausanne) 2020, 10(910).

39. Christensen El, Birn H: Megalin and cubilin: multifunctional endocytic receptors. Nature reviews Molecular cell biology 2002, 3(4):256-266.

40. Nykjaer A, Fyfe JC, Kozyraki R, Leheste JR, Jacobsen C, Nielsen MS, Verroust PJ, Aminoff M, de la Chapelle A, Moestrup SK et al: Cubilin dysfunction causes abnormal metabolism of the steroid hormone $25(\mathrm{OH})$ vitamin $\mathrm{D}(3)$. Proceedings of the National Academy of Sciences of the United States of America 2001, 98(24):13895-13900.

41. Mahadevappa R, Nielsen R, Christensen El, Birn H: Megalin in acute kidney injury: foe and friend. American Journal of Physiology-Renal Physiology 2014, 306(2):F147-F154.

42. Negri AL: Proximal tubule endocytic apparatus as the specific renal uptake mechanism for vitamin Dbinding protein/25-(OH)D3 complex. Nephrology (Carlton, Vic) 2006, 11(6):510-515.

43. Nykjaer A, Dragun D, Walther D, Vorum H, Jacobsen C, Herz J, Melsen F, Christensen El, Willnow TE: An endocytic pathway essential for renal uptake and activation of the steroid 25-(OH) vitamin D3. Cell 1999, 96(4):507-515.

44. Thrailkill KM, Nimmo T, Bunn RC, Cockrell GE, Moreau CS, Mackintosh S, Edmondson RD, Fowlkes $\mathrm{JL}$ : Microalbuminuria in type 1 diabetes is associated with enhanced excretion of the endocytic multiligand receptors megalin and cubilin. Diabetes care 2009, 32(7):1266-1268.

45. Leheste JR, Melsen F, Wellner M, Jansen P, Schlichting U, Renner-Müller I, Andreassen TT, Wolf E, Bachmann S, Nykjaer A et al: Hypocalcemia and osteopathy in mice with kidney-specific megalin gene defect. FASEB journal : official publication of the Federation of American Societies for Experimental Biology 2003, 17(2):247-249.

46. Anderson RL, Ternes SB, Strand KA, Rowling MJ: Vitamin D homeostasis is compromised due to increased urinary excretion of the 25-hydroxycholecalciferol-vitamin D-binding protein complex in the Zucker diabetic fatty rat. American journal of physiology Endocrinology and metabolism 2010, 299(6):E959-967.

47. Fowlkes J, Bunn R, Cockrell G, Clark L, Wahl E, Lumpkin C, Thrailkill K: Dysregulation of the Intrarenal Vitamin D Endocytic Pathway in a Nephropathy-Prone Mouse Model of Type 1 Diabetes. Experimental diabetes research 2011, 2011:269378.

48. Thrailkill KM, Jo CH, Cockrell GE, Moreau CS, Fowlkes JL: Enhanced excretion of vitamin D binding protein in type 1 diabetes: a role in vitamin D deficiency? The Journal of clinical endocrinology and metabolism 2011, 96(1):142-149. 
49. Fisher CE, Howie SEM: The role of megalin (LRP-2/Gp330) during development. Developmental Biology 2006, 296(2):279-297.

50. Zheng G, Bachinsky DR, Stamenkovic I, Strickland DK, Brown D, Andres G, McCluskey RT: Organ distribution in rats of two members of the low-density lipoprotein receptor gene family, gp330 and LRP/alpha 2MR, and the receptor-associated protein (RAP). The journal of histochemistry and cytochemistry : official journal of the Histochemistry Society 1994, 42(4):531-542.

51. Aksoy H, Akçay F, Kurtul N, Baykal O, Avci B: Serum 1, 25 dihydroxy vitamin D (1, 25 (OH) 2D3), 25 hydroxy vitamin $\mathrm{D}(25(\mathrm{OH}) \mathrm{D})$ and parathormone levels in diabetic retinopathy. Clinical biochemistry 2000, 33(1):47-51.

52. Reheem RNAMA, Fattah MAHMA: Serum vitamin D and parathormone (PTH) concentrations as predictors of the development and severity of diabetic retinopathy. Alexandria Journal of Medicine 2013, 49(2):119-123.

53. Taverna MJ, Selam J-L, Slama G: Association between a protein polymorphism in the start codon of the vitamin $\mathrm{D}$ receptor gene and severe diabetic retinopathy in C-peptide-negative type 1 diabetes. The Journal of Clinical Endocrinology \& Metabolism 2005, 90(8):4803-4808.

54. Suzuki A, Kotake M, Ono Y, Kato T, Oda N, Hayakawa N, Hashimoto S, Itoh M: Hypovitaminosis D in type 2 diabetes mellitus: association with microvascular complications and type of treatment. Endocrine journal 2006:0607070010-0607070010.

55. Mitnick MA, Grey A, Masiukiewicz U, Bartkiewicz M, Rios-Velez L, Friedman S, Xu L, Horowitz MC, Insogna K: Parathyroid hormone induces hepatic production of bioactive interleukin- 6 and its soluble receptor. American Journal of Physiology-Endocrinology and Metabolism 2001, 280(3):E405-E412.

56. Yamamoto N: Vitamin D and the Immune System. In: Encyclopedia of Immunology (Second Edition). edn. Edited by Delves PJ. Oxford: Elsevier; 1998: 2494-2499.

57. Bouillon R, Pauwels S: Chapter 7 - The Vitamin D-Binding Protein. In: Vitamin D (Fourth Edition). edn. Edited by Feldman D: Academic Press; 2018: 97-115.

58. Baelen H, Bouillon R, Moor P: Vitamin D-binding protein (Gc-Globulin) binds actin. The Journal of biological chemistry 1980, 255:2270-2272.

59. Nagasawa H, Uto Y, Sasaki H, Okamura N, Murakami A, Kubo S, Kirk KL, Hori H: Gc protein (vitamin D-binding protein): Gc genotyping and GcMAF precursor activity. Anticancer research 2005, 25(6a):3689-3695.

60. Murugeswari P, Shukla D, Rajendran A, Kim R, Namperumalsamy P, Muthukkaruppan V: Proinflammatory cytokines and angiogenic and anti-angiogenic factors in vitreous of patients with proliferative diabetic retinopathy and eales' disease. Retina (Philadelphia, Pa) 2008, 28(6):817-824.

61. Ghasemi H, Ghazanfari T, Yaraee R, Faghihzadeh S, Hassan ZM: Roles of IL-8 in ocular inflammations: a review. Ocular immunology and inflammation 2011, 19(6):401-412.

62. Parameswaran N, Patial S: Tumor necrosis factor-a signaling in macrophages. Critical reviews in eukaryotic gene expression 2010, 20(2):87-103. 
63. Aveleira CA, Lin CM, Abcouwer SF, Ambrósio AF, Antonetti DA: TNF-a signals through PKCZ/NF-kB to alter the tight junction complex and increase retinal endothelial cell permeability. Diabetes 2010, 59(11):2872-2882.

64. Madigan MC, Sadun AA, Rao NS, Dugel PU, Tenhula WN, Gill PS: Tumor necrosis factor-alpha (TNFalpha)-induced optic neuropathy in rabbits. Neurological research 1996, 18(2):176-184.

65. Majka S, McGuire PG, Das A: Regulation of matrix metalloproteinase expression by tumor necrosis factor in a murine model of retinal neovascularization. Investigative ophthalmology \& visual science 2002, 43(1):260-266.

66. Guarda G, So A: Regulation of inflammasome activity. Immunology 2010, 130(3):329-336.

67. Vincent JA, Mohr S: Inhibition of caspase-1/interleukin-1 beta signaling prevents degeneration of retinal capillaries in diabetes and galactosemia. Diabetes 2007, 56(1):224-230.

68. Iqbal K, Islam N, Azam I, Asghar A, Mehboobali N, Iqbal MP: Association of Vitamin D binding protein polymorphism with risk of type 2 diabetes mellitus in a Pakistani urban population: A case control study. JPMA The Journal of the Pakistan Medical Association 2017, 67(11):1658-1663.

69. Wang G, Li Y, Li L, Yu F, Cui L, Ba Y, Li W, Wang C: Association of the vitamin D binding protein polymorphisms with the risk of type 2 diabetes mellitus: a meta-analysis. BMJ Open 2014, 4(11):e005617.

70. Szathmary EJE: The effect of Gc genotype on fasting insulin level in Dogrib Indians. Human genetics 1987, 75(4):368-372.

71. Ye W-Z, Dubois-Laforgue D, Bellanné-Chantelot C, Timsit J, Velho G: Variations in the vitamin Dbinding protein (Gc locus) and risk of type 2 diabetes mellitus in French Caucasians. Metabolism Clinical and Experimental 2001, 50(3):366-369.

72. Miller JR, Lechler PJ, Mackin G, Germanoski D, Villarroel LF: Evaluation of particle dispersal from mining and milling operations using lead isotopic fingerprinting techniques, Rio Pilcomayo Basin, Bolivia. Science of The Total Environment 2007, 384(1):355-373.

73. Braun A, Bichlmaier R, Cleve $\mathrm{H}$ : Molecular analysis of the gene for the human vitamin-D-binding protein (group-specific component): allelic differences of the common genetic GC types. Human genetics 1992, 89(4):401-406.

74. Ravnsborg T, Olsen DT, Thysen AH, Christiansen M, Houen G, Højrup P: The glycosylation and characterization of the candidate Gc macrophage activating factor. Biochimica et Biophysica Acta (BBA) - Proteins and Proteomics 2010, 1804(4):909-917.

\section{Figures}




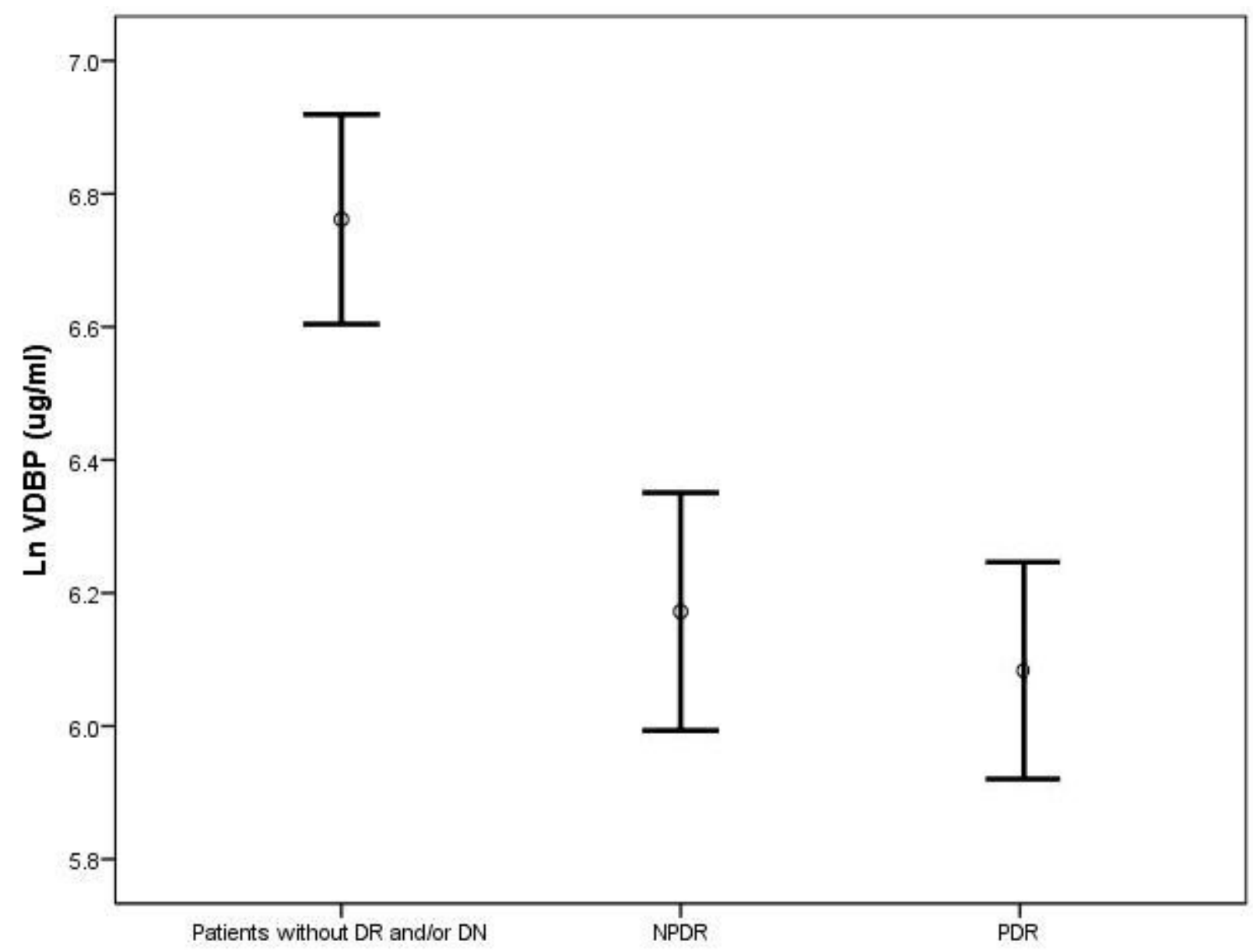

Figure 1

Comparison of VDBP levels between proliferative retinopathy, non-proliferative diabetic retinopathy, and no retinopathy in diabetic patients 